\title{
Understanding Supply Chain Management from a Main Contractor's Perspective
}

Emmanuel Manu and Andrew Knight

\subsection{Introduction}

The emergence of supply chain management in construction was predominantly driven by major clients who began to adopt procurement arrangements such as prime contracting, partnering, and framework agreements. These were major clients who had the power leverage to mobilise construction firms for projects that spanned a considerable timeframe. Despite such early efforts towards supply chain management adoption, it increasingly became apparent that numerous subcontractors and suppliers were not fully integrated into these supply chain driven collaborative approaches. This has remained a key shortcoming of such collaborative efforts in the construction sector (Kumaraswamy et al. 2010). This situation has now burdened main contractors with the enormous responsibility of coordinating and managing multilayered tiers of suppliers and subcontractors for production and value addition across multiple projects. Main contractors have taken an interest in supply chain management as an approach for coordinating upstream linkages with demand-side organisations, in addition to the downstream tiers of supply chain firms assembled to deliver projects. However, empirical evidence of supply chain management initiatives and practices that have been implemented by main contractors to manage the lower tiers of the supply chain remains scarce (Pala et al. 2014; Broft et al. 2016).

In this chapter, the multilayered nature of subcontracting in construction will be discussed, together with its ramifications, before reviewing literature on supply chain management principles and practices that can be adopted by main contractors. A case study of supply chain management practices implemented by a large UK main contractor is then used to provide some empirical evidence of supply chain management adoption from a main contractor's perspective. This case study focuses on the 'dyadic' relationship between a Tier 1 main contractor and Tier 2 subcontractors. 


\subsection{Multilayered Subcontracting in the Construction Industry}

Construction work is specialist in nature and historically has involved input from different specialist firms. Prior to the recognition that the supply chain management concept could be harnessed for the management of these supply chain firms, main contractors had always depended on, and worked with, a pool of subcontractor firms available to them from the market. Main contractors, who are tasked with the ultimate responsibility of carrying out and completing construction projects, have often relied on subcontractors for the provision of specialised works and services. Beyond the need to subcontract specialist aspects of construction works, there has also been a growth in labour-only subcontracting which in the case of the British construction industry, has resulted from the strategic choice by construction companies to emphasise flexibility over productivity as a source of competitive advantage (Winch 1998). This flexibility allows main contractors to cope with constant fluctuations in demand for their services. Evidence suggests that subcontracted work can constitute up to $90 \%$ of construction work by value on most projects (Segerstedt et al. 2010). As shown in Figure 12.1, the nature of subcontracting practice in construction is also multilayered (Ronchi 2006; Broft et al. 2016), with Tier 1 contractors depending on a network of Tier 2 and Tier 3 subcontractors and suppliers to achieve production. A similar pattern of multilayered subcontracting also persists amongst in-use suppliers. A typical construction project will usually involve a complex network of interactions between multiple tiers of production suppliers that have to work together to meet the needs of the demand-side organisation(s).

Another characteristic of the construction supply chain is that it is typically a make-to-order supply chain, with every project 'tailor made' to the client's specifications (Ronchi 2006). Information flow across the supply chain commences from the demand organisations (clients and users) in the form of client requirements, through Tier 1 contractors and across the different tiers of the production supply chain. There are consequently material and information flows in the opposite direction, through to the demand organisations and in-use supply chain. Main contractors have the arduous task of managing and coordinating the various subcontractors and suppliers, and managing the associated risks to deliver a successful project. This task of coordinating and managing the complex supply chain network can be challenging and an issue that is often underestimated is the concurrent involvement of specialist contractors on other projects and their inability to manage constrained resources across multiple projects concurrently (Ronchi 2006).

This multilayered nature of subcontracting practice has been attributed to several problems in construction. Inadequate coordination and management of the network of specialist firms that are assembled to deliver projects has been linked to poor planning, lack of information, and faulty materials (Thunberg et al. 2017). Chiang (2009) and Tam et al. (2011) have also suggested that poor quality building products undermine the effectiveness of the multilayered supply chain in Hong Kong. Manu et al. (2013) have highlighted the adverse health and safety performance implications of subcontracting practice and the need to devise strategies that can minimise these adverse health and safety implications. These negative implications of multilayered subcontracting, coupled with the responsibility that main contractors have to mobilise, coordinate, and manage a large number of subcontractors and suppliers on projects has prompted a deepening interest in supply chain management. 


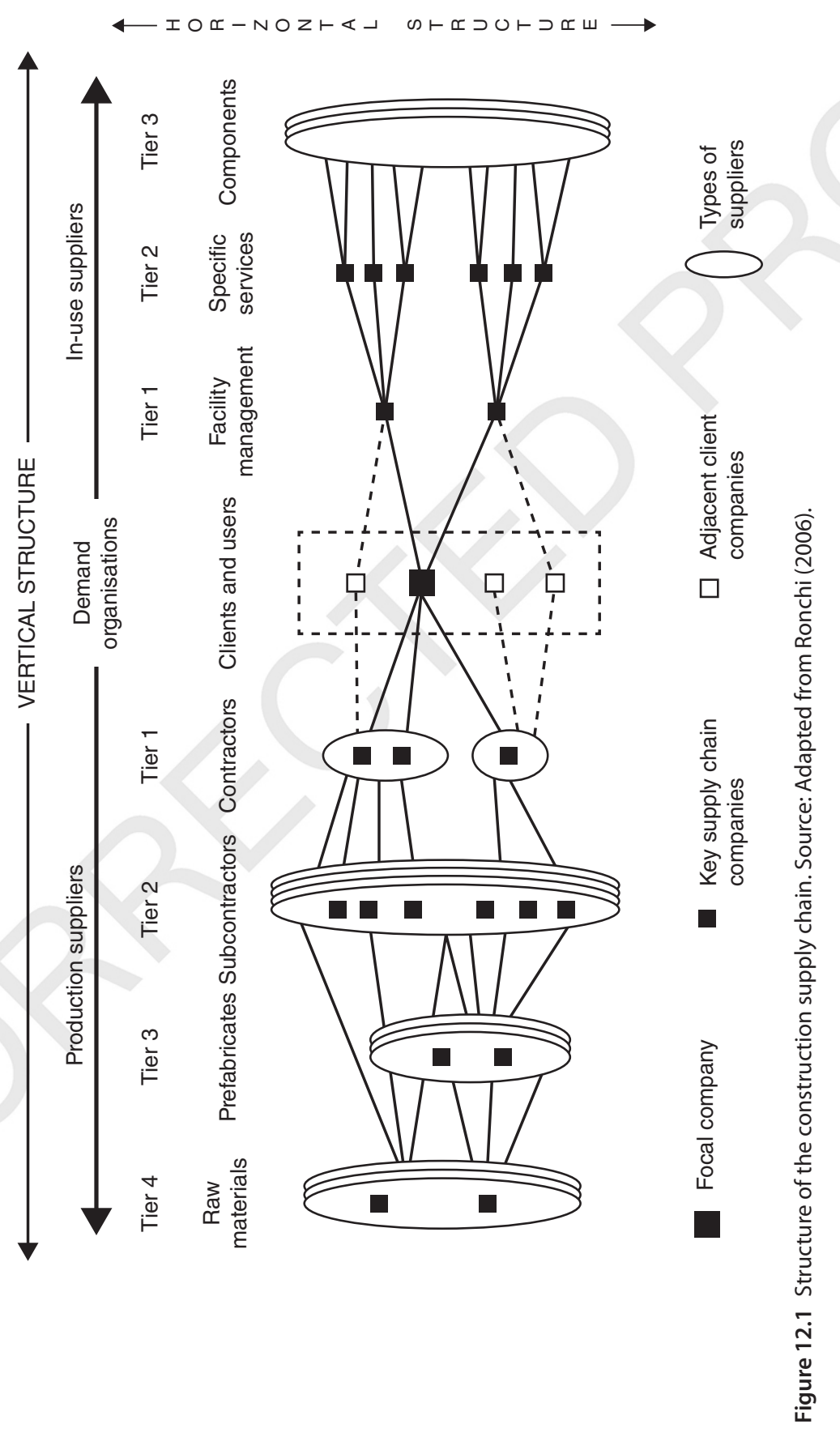


The position of main contractors in the construction supply chain has enabled them to adopt and apply supply chain management to the management of subcontractors and suppliers across the downstream tiers, in addition to coordinating upstream linkages with demand-side organisations. Karim et al. (2006) and Smyth (2010) have also argued that the era of shifts towards integrated project delivery and relationship development in the UK construction industry has presented main contractors with an opportunity to increase their role in the market by managing a greater number of stakeholders to facilitate collaborative working. So whilst an unbalanced emphasis has been placed on client-driven supply chain management approaches in construction, it is equally important to examine supply chain management from the main contractor's perspective. This view is supported by Arantes et al. (2015), who has argued that to improve upon construction project delivery through supply chain management adoption, it is important to give specific attention to the relationship interface between main contractors, subcontractors, and suppliers and how these have been influenced by supply chain management adoption.

\subsection{Supply Chain Management: Principles and Practices}

Supply chain management has been defined widely in the literature, with much more agreement on the definition of 'supply chains' than for definitions of the supply chain management concept (Mentzer et al. 2001). Christopher (2011, p. 13) defined supply chains as 'the network of organisations that are involved through upstream and downstream linkages, in the different processes and activities that contribute value in the form of a product or service delivered to an ultimate consumer'. Christopher then defined supply chain management as 'the management of upstream and downstream relationships with suppliers and customers in order to deliver superior customer value at less cost to the supply chain as a whole' (Christopher 2011, p. 3). The Global Supply Chain Forum has also defined supply chain management as 'an integration of key business processes from end user through original product suppliers with the aim of providing products, services, and information that add value for customers and other stakeholders' (Cooper et al. 1997, p. 2). Lönngren et al. (2010, p. 404) similarly defined supply chain management as 'the task of integrating organisational units along a supply chain and coordinating materials, information and financial flows to fulfil customer demand and improve competitiveness of a supply chain as a whole'.

Supply chain management as a concept extends beyond the logistics thinking as it integrates the management of cooperative relationships with the logistical concerns of material and information flows (Ashby et al. 2012). Mentzer et al. (2001) classified supply chain management as comprising a management philosophy, implementation of a management philosophy, and a set of management processes. The common themes that run through the various definitions imply that supply chain management requires the application of a management philosophy to facilitate the integration of key business processes across supply chain organisations so that they can react as a single entity to market demands, enhance their long-term competitive advantage, and ultimately add value to clients, customers, and end users.

In the UK construction industry, a significant landmark in the evolutionary process of supply chain management adoption was the 'Building Down Barriers' initiative by 
Figure 12.2 Seven principles of supply chain management. Source: Holti et al. (2000).

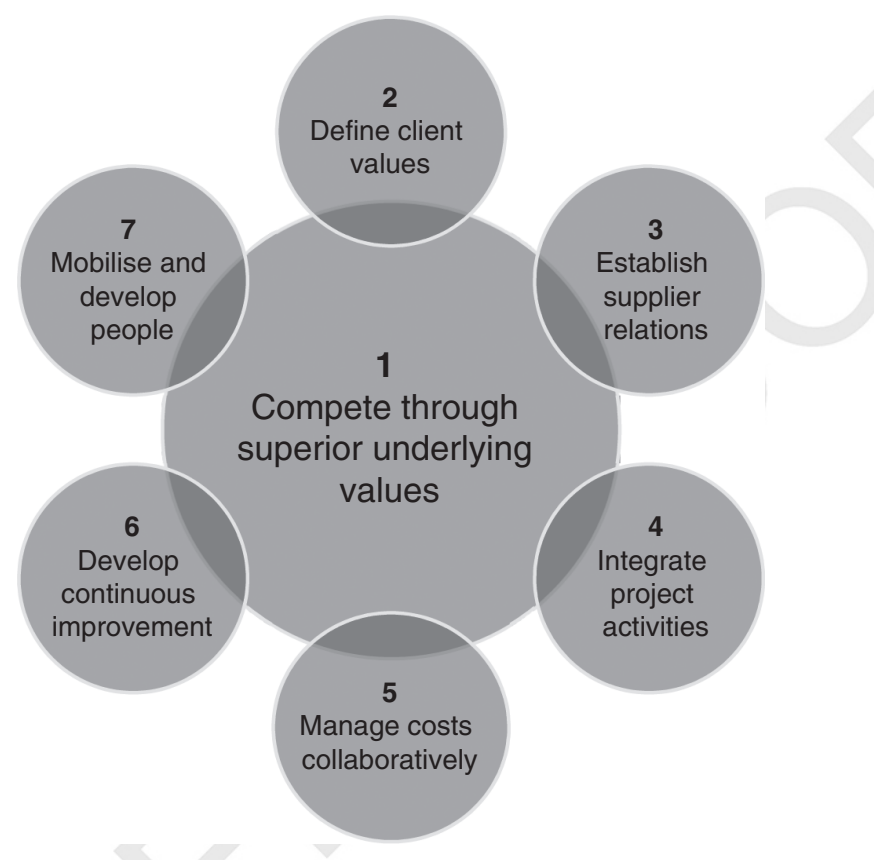

the UK Ministry of Defence (MOD) (Holti et al. 2000). Seven principles were developed based on two pilot projects that were awarded to prime contractors AMEC and Laing in 1997 as an initiative to establish working principles of supply chain integration in construction. These seven principles of supply chain management (see Figure 12.2) were advocated for adoption in the construction industry.

Broft et al. (2016) have thoroughly discussed these seven principles as essential ingredients required for a construction company to function in a supply chain managementdriven environment. The first principle 'compete through superior underlying value' requires that the construction supply chain develops a good understanding of the client's perception of value and uses their capabilities to improve quality and reduce unnecessary costs. To achieve this underlying principle, the other six principles will have to be embraced. The second principle 'define client values' requires a rigorous assessment and definition of client value priorities in terms of functional requirements, design character, and whole-life costs. The third principle 'establish supplier relationship' relates to the commitment of forming long-term relationships with a small number of suppliers which can help to improve communication and mutual understanding. The fourth principle 'integrate project activities' relates to collaboration on project activities to resolve design and construction-related issues at the early stages of a project and during the construction phase. The fifth principle 'manage costs collaboratively' advocates for collaborative efforts to develop target costs based on the client's requirements. The sixth principle 'develop continuous improvement' is concerned with the need for long-term efforts to innovate continuously to improve the functionality and value of projects and reduce unnecessary costs, not just across the life of one project but across multiple projects through long-term collaborations. The seventh principle 'mobilise and develop people' relates to the substantial cultural change that is required for successful supply chain 
management implementation through training in new skills and provision of economic incentives.

These supply chain management principles have driven various practices in the UK construction sector. Fernie and Tennant (2013) have differentiated between client-led and contractor-led supply chain management practices. They likened client-led supply chain management practices to the emergence and use of procurement arrangements like framework agreements to legitimise clusters of organisations led by a principal supply chain partner (contractor) and an associated principal supply chain member (consultant). However, since the number of client organisations that have the financial and operational capacity to procure an ongoing and significant volume of projects can be limited, contractor-led supply chain management practices need evaluating from the perspective of formalised institutions that have been created by main contractors to facilitate integration and collaboration with a network of supply chain firms.

\subsection{Supply Chain Management Practices from a Contractor's Perspective}

Supply chain management as a concept can be viewed as consisting of processes, management activities, and a supply chain structure (Lambert and Cooper 2000). From a process viewpoint, supply chain management has been applied to business processes like logistics, distribution, and off-site and on-site production and assembly. Beyond the application of supply chain management to logistics and distribution processes, main contractors have used supply chain management to improve management activities associated with the coordination and integration of the supply chain and promoting the levels of cooperation that is required to achieve successful on-site production (Thunberg and Fredriksson 2018). The Egan Report (Egan 1998), which is one of the earliest publications to advocate supply chain management adoption in the UK construction industry, specifically recommended seven features that should be promoted:

1. Acquisition of new suppliers through value-based sourcing.

2. Organisation and management of the supply chain to maximise innovation.

3. Learning and efficiency.

4. Supplier development and measurement of suppliers' performance.

5. Management of workload to match capacity.

6. Incentivisation of suppliers to improve performance.

7. Capture of suppliers' innovations in components and systems.

These supply chain management features underpin to some extent the seven principles of supply chain management that were later advocated by Holti et al. (2000). Other studies have continued to discuss different aspects of supply chain management practice being adopted by construction organisations, all of which fit within the supply chain management principles proposed by Holti et al. (2000) and the above features recommended for supply chain management adoption. For instance, it is considered important that main contractors devise practices for organising and managing the number of firms that constitute their supply chain (Gosling et al. 2010). Category management has emerged as a consistent practice that main contractors adopt for this purpose (Fernie and Tennant 2013). Category management protocols have been implemented by main contractors through the use of explicit labels such as preferred 
supplier, approved supplier, and pre-approved supplier for categorisation and management of their supplier base (Fernie and Tennant 2013). Ronchi (2006) also differentiated between main contractor practices for managing the supplier base by using the size of the supply base, the existence of an internal classification amongst the suppliers, and the connectivity that is achieved in the network of relationships.

Another important aspect of a contractor-led supply chain management practice relates to how they manage supply chain performance (Cheng et al. 2010; Behera et al. 2015). Fernie and Tennant (2013) revealed the widespread use of formalised prequalification questionnaires (PQQs), key performance indicators (KPIs), and benchmarking by main contractors to categorise and accredit suppliers. The measurement of supplier performance is also strongly linked to continuous performance improvement initiatives with the supply chain, which can only be achieved through supply chain collaboration (Eriksson 2010). Main contractor collaborations with the supply chain has also been linked to planning activities, with supply chain planning emerging as a contractor-led supply chain management practice of involving supply chain actors in the planning process through supply of relevant information for on-site production (Thunberg and Fredriksson 2018). Thunberg and Fredriksson (2018) argued that supply chain planning is an important aspect of supply chain management practice that can improve efficiency of the construction process and facilitate supply chain management adoption. In order to enhance supply chain collaboration, there has also been a significant emphasis on the main contractor's adoption and use of information and communication technologies (ICT), which can improve coordination and information flow amongst supply chain actors (Ronchi 2006; Lönngren et al. 2010; Pala et al. 2014). Pala et al. (2014) revealed that the adoption of relationship management approaches by main contractors, as part of their supply chain management drive, was directly or indirectly facilitated by ICT. There is also a need for main contractors to adopt practices that incentivise and motivate the supply chain to collaborate as part of any supply chain management drive. It has been widely acknowledged that true collaboration in the construction supply chain can only be achieved if benefits are mutually shared. A typical approach is the need to promote fair and prompt payment practices in the supply chain (Manu et al. 2015).

From the above discussion, supply chain management from the main contractor's perspective seems to revolve around practices that support integration and collaboration with supply chain firms through information sharing, performance measurement, continuous improvements, and innovations, and sharing of rewards, with the ultimate view of achieving a competitive edge in the market and delivering better quality projects for clients and end users whilst eradicating unnecessary costs.

\subsection{Case Study of a Large UK Main Contractor}

A case study approach was used to explore the supply chain management practices of a main contractor in the UK which for the sake of anonymity, is presented here as $\mathrm{ABC}$ Construction Company. $\mathrm{ABC}$ Construction Company is a major player in the UK construction industry with over $£ 1$ billion annual turnover and operates a network of seven regional offices. They employ a considerable number of subcontractors and suppliers across many projects annually and have adopted supply chain management as a strategy for managing the network of firms that they work with to deliver projects. The case study approach was adopted for the study because it 
allowed for in-depth exploration of supply chain management practices within the main contractor's organisational context, and facilitated evidence gathering from multiple sources (Proverbs and Gameson 2008; Yin 2013). Data on their supply chain management practices was gathered through a supply chain management workshop in $\mathrm{ABC}$ Construction Company's premises, direct observations during project meetings, a review of supply chain policy documents and semistructured interviews with both main contractor and subcontractor personnel. In total, eleven participants were interviewed to explore the supply chain management practices of $A B C$ Construction Company (see Table 12.1). The data was analysed using thematic analysis, which is a core qualitative data analysis method for identifying, analysing, and reporting patterns (themes) within data (Braun and Clarke 2006). The thematic analysis process involved:

- Transcription and initial familiarisation with the data.

- Coding interesting features of the data.

- Collating codes into potential themes.

- Reviewing themes and presenting results.

A main theme that emerged from the analysis was on the 'Main Contractor's Supply Chain Management Features'. This main theme had four categories: 'supply chain management goals', 'supply chain management team', 'supply chain classification', and 'supply chain management practices'. The category on 'supply chain management practices' further consisted of six subcategories that were reflective of $\mathrm{ABC}$ Construction Company's supply chain management practices - which will be discussed in the sections that follow.

\subsubsection{Supply Chain Management Goals}

Having adopted supply chain management as a management philosophy within their business, $\mathrm{ABC}$ Construction had to establish clear goals that had to be promoted through supply chain management adoption. The following supply chain management goals emerged from the analysis of the data - to:

- Rationalise the number of subcontractors used across projects.

- Audit health and safety, design, employment policy, financial stability, and other aspects of performance before a supply chain firm works on any project.

Table 12.1 Semi-structured interview participants.

\begin{tabular}{ll}
\hline ABC Construction Company & Supply chain subcontractors \\
\hline 1. Supply chain manager & 1. Project manager - Mechanical and Electrical (M\&E) Services \\
2. Construction manager & 2. Contracts manager - Roofing \\
3. Senior quantity surveyor & 3. Director - Scaffolding \\
4. Project quantity surveyor & 4. Quantity surveyor - Scaffolding \\
& 5. Contracts director - Carpentry and Joinery \\
& 6. Director - Tiling and Mosaic \\
& 7. Operations manager - Panelling \\
\hline
\end{tabular}

Source: Original 
- Have better quality supply chain firms working across projects to deliver innovative and sustainable solutions to clients.

- Collaborate with supply chain firms to promote improved health and safety, build quality, better integration, and materials management, improved sustainability and business ethics, reduced waste, less claims; and fewer defects across projects.

- Allow feedback on project performance to influence future work with the supply chain.

- Share information with subcontractors and to reduce paperwork whilst raising standards.

- Develop greater understanding and trust and improved communication with the supply chain and deliver best results to clients.

- Facilitate regular reviews with key supply chain partners, monitor performance and changes in the business, and set improvement areas.

- Increase spending with strategic and high performing subcontractors where appropriate.

These supply chain management goals all revolved around the development of closer collaboration with supply chain subcontractors that were competent. This could only be achieved by setting goals to select competent supply chain subcontractors based on performance, then collaborate with these firms through increased spending, better communication, information sharing, and integration and continuous improvements across projects, facilitated by performance feedbacks. These goals are very reflective of the supply chain management principles recommended by Holti et al. (2000). In the case of $\mathrm{ABC}$ Construction, no explicit goal was set on managing cost collaboratively. However, collaboration was linked to the wider issues of health and safety performance, build quality, better materials management, better integration, improved business ethics, reduced waste, fewer claims, and fewer defects. This range of collaboration issues as set in the supply chain management goals are reflective of ABC Construction's areas of interest as a main contractor. To achieve these goals, $\mathrm{ABC}$ Construction had to establish a supply chain management team.

\subsubsection{Supply Chain Management Team}

ABC Construction appointed Regional Supply Chain Managers across the seven regional branches in the UK. These managers had responsibility for managing a regional team of supply chain management personnel that would act as company contact persons with subcontractors and suppliers that were to become part of their supply chain. As shown in Figure 12.3, the Regional Supply Chain Managers reported to a national (UK) Supply Chain Management Coordinator who had oversight responsibility for setting policy and promoting the supply chain management philosophy within the business. The Supply Chain Coordinator reported to an Executive Director for the construction aspect of the business. A Database Manager was also appointed with responsibility for managing data and information on supply chain firms. The Database Manager had to work closely with the Supply Chain Management Coordinator, an indication of the importance that $\mathrm{ABC}$ Construction attached to the management of supply chain data and information as part of their supply chain management practice.

$A B C$ Construction's supply chain management team acted as supply chain management champions to promote and embed the supply chain management practices within 


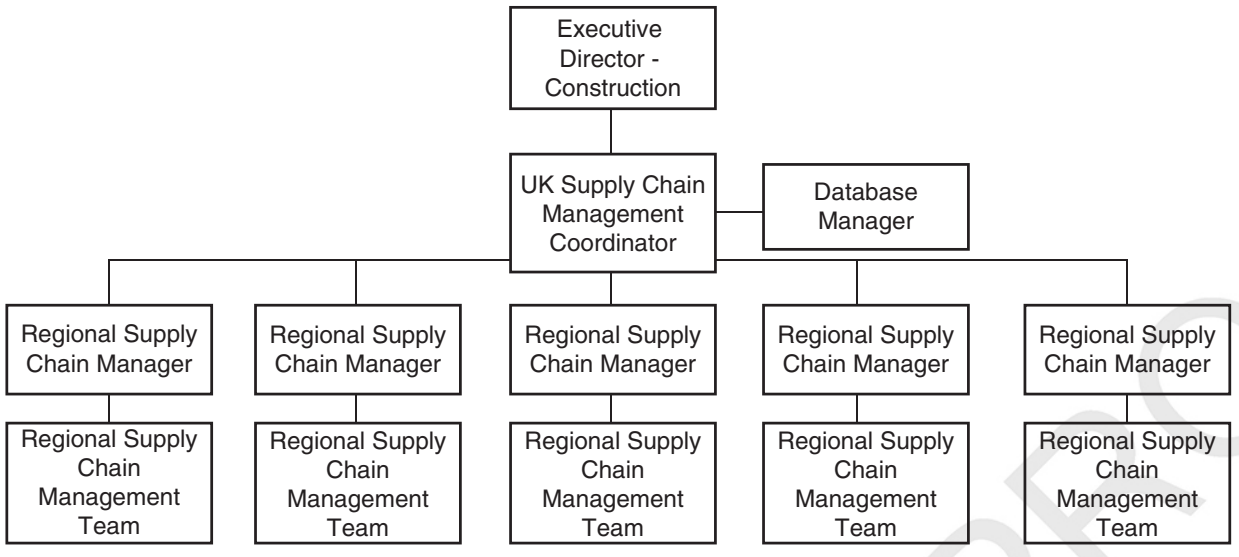

Figure 12.3 Structure of ABC Construction Company's supply chain management team. Source: Original.

the organisation. As remarked by the Contracts Manager for the Carpentry and Joinery Subcontractor:

...they [ABC Construction] have a face...[to]..their supply chain, they've got a [supply chain manager] who involves himself with the subcontractors, which I think is a positive thing to have and they..[allocate to]... you.. a person, basically, your contact if anything goes wrong.... not a lot of companies have that. So, it's got structure and I think it certainly seems to work better than most of the other companies out there.

Supply chain subcontractors recognised ABC Construction's commitment to promoting supply chain management within their business through an established and well-structured supply chain management department. Participants from the supply chain firms that were interviewed felt that $A B C$ Construction's supply chain management initiative worked because of the availability of dedicated teams that they could speak to on supply chain management related issues.

\subsubsection{Supply Chain Management Classification}

$\mathrm{ABC}$ Construction also adopted a four-level internal classification system for their supply chain. This classification structure (see Figure 12.4) was institutionalised as the platform for rationalising the number of subcontractors used within the business.

This classification structure provided a platform for implementing the supply chain management practices. As part of the goal to rationalise the number of supply chain firms that $\mathrm{ABC}$ Construction works with, this four-level classification was intended to define the number of firms, specify performance requirements, define the nature of relationships that should be promoted, the level of collaboration to pursue, the degree of emphasis to place on continuous performance improvements, and the formality of long-term relationships in the supply chain classes. This classification structure therefore influenced the supply chain management practices discussed in the next section. 
Level 1 - Strategic

Subcontractors have been endorsed as best/better performers and proceeded to sign long-term supply chain agreements with $\mathrm{ABC}$ Construction. This status is only achieved through audits and a series of meetings between both parties working through the terms and conditions and agreeing the way forward, with annual reviews that give both parties an opportunity to discuss working relationship, performance analysis, and continuous improvement areas, airing both positive and negative aspects of the agreement

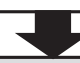

Level 2 - Preferred

Subcontractors work closely with $\mathrm{ABC}$ Construction on a regular basis, a relationship has developed over severa years, and a good level of trust exists between both parties. Although no formal long-term supply chain agreements have been signed, subcontractors are eligible for, or are working towards, the next level of supply chain collaboration.

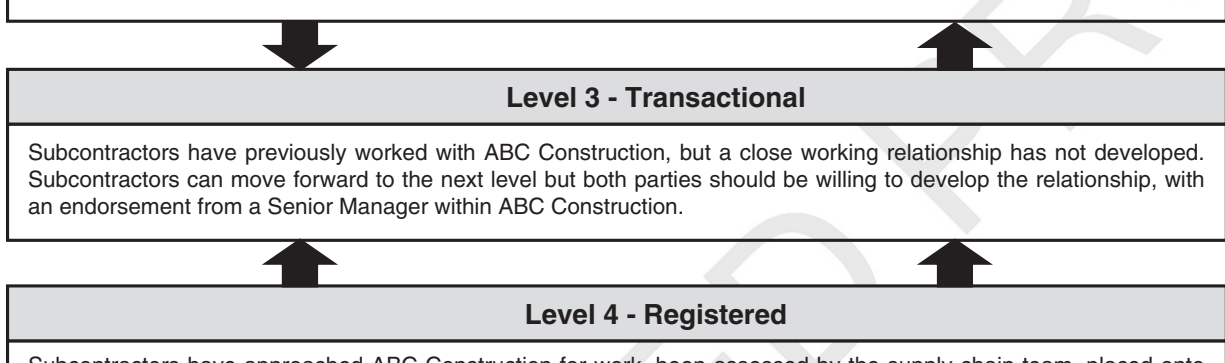

Subcontractors have approached $A B C$ Construction for work, been assessed by the supply chain team, placed onto the database in preparation for a potential future working relationship, but have not yet undertaken any work.

Figure 12.4 Status of supply chain firms on contractor ABC Construction Company's database. Source: Original.

\subsubsection{Supply Chain Management Practices}

The 'supply chain management practices' category had six subcategories that encompassed ABC Construction's key supply chain management practices (see Table 12.2). These supply chain management practices were to:

- Audit supply chain firms.

- Use collaborative ICT systems.

- Measure performance of supply chain firms.

- Engage in continuous performance improvement activities.

- Develop long-term collaborative relationships.

- Motivate and incentivise the supply chain.

These supply chain management practices will be discussed in the sections that follow.

\subsubsection{Audit Supply Chain Firms}

Before any subcontractor could undertake work for ABC Construction, they had to be registered onto the supply chain database (see Figure 12.4), which required a rigorous supply chain audit. This audit involved standard company checks such as assessment of company registration information, health and safety documentation, insurance documentation, organisational structure, financial stability checks, key contact persons, and other details that could prove past performance. A standardised 
Successful Construction Supply Chain Management

Table 12.2 Supply chain management practices promoted by ABC Construction Company.

\begin{tabular}{|c|c|}
\hline Practices & Manifestations \\
\hline Audit supply chain firms & $\begin{array}{l}\text { Supply chain interviews and audits on health and safety, design, } \\
\text { employment policy, financial stability, collection of necessary } \\
\text { references, commercial checks, and office visits where necessary }\end{array}$ \\
\hline $\begin{array}{l}\text { Use collaborative ICT } \\
\text { systems }\end{array}$ & $\begin{array}{l}\text { Bespoke IT system with a database that held vital details of } \\
\text { subcontractors such as trading information, supply chain status, } \\
\text { project preferences, performance scores, including key contact } \\
\text { persons for each subcontractor. IT system also supported e-tendering }\end{array}$ \\
\hline $\begin{array}{l}\text { Measure performance of } \\
\text { supply chain firms }\end{array}$ & $\begin{array}{l}\text { Performance scoring on health and safety, standard of work, } \\
\text { compliance with programme, contractual cooperation, financial } \\
\text { cooperation, supervision of work and design input where applicable. } \\
\text { Health and safety scorings revealed and discussed with all } \\
\text { subcontractors on the project whilst other scores are only revealed } \\
\text { and discussed with Level } 1 \text { subcontractors during annual review } \\
\text { meetings. Performance scores are continuously logged on IT system }\end{array}$ \\
\hline $\begin{array}{l}\text { Engage in continuous } \\
\text { performance } \\
\text { improvement activities }\end{array}$ & $\begin{array}{l}\text { Annual meetings with Level } 1 \text { (see Figure } 12.4 \text { ) subcontractors to } \\
\text { review performance with allocated supply chain contact person and } \\
\text { set improvement areas. All subcontractors on database allocated a } \\
\text { supply chain point of contact }\end{array}$ \\
\hline $\begin{array}{l}\text { Develop long-term } \\
\text { collaborative relationships }\end{array}$ & $\begin{array}{l}\text { Formal long-term supply chain agreements signed with only Level } 1 \\
\text { subcontractors. Tendering assistance is provided by Level } 1 \text { supply } \\
\text { chain through design input, collaborative planning, and costing }\end{array}$ \\
\hline $\begin{array}{l}\text { Motivate and incentivise } \\
\text { the supply chain }\end{array}$ & $\begin{array}{l}\text { Provided tendering priority based on subcontractor's supply chain } \\
\text { status, with on average } 50 \% \text { of annual national spend going to Level } 1 \\
\text { supply chain subcontractors and this was as high as } 80 \% \text { on average } \\
\text { in some regional branches. Gave out an annual supply chain award to } \\
\text { the best performing subcontractor. Strived to promote a } 30 \text { days } \\
\text { payment arrangement across the supply chain }\end{array}$ \\
\hline
\end{tabular}

Source: Original

supply chain questionnaire was used to obtain aspects of the data. In some instances where it became necessary to acquire further information about a subcontractor's office set-up and facilities, ABC Construction's supply chain personnel conducted company visits. Throughout these audits, emphasis was placed on the business initiatives that $\mathrm{ABC}$ Construction was promoting such as on building information modelling (BIM), sustainability, and zero harm health and safety targets. Audited and registered supply chain firms were also allocated a supply chain contact person from $\mathrm{ABC}$ Construction. This became the starting point of relationship development as part of $\mathrm{ABC}$ Construction's supply chain management approach. The allocated supply chain contact persons also acted as supply chain management champions by acting as liaison with ABC Construction's project management team and the supply chain subcontractors.

These audits were used to develop $\mathrm{ABC}$ Construction's organisational supply chain rather than for the sole purpose of performing procurement checks for a project. The emphasis that $A B C$ Construction's supply chain team placed on these supply chain audits reflects the importance of the need for careful evaluation and selection of potential supply chain firms (Seth et al. 2018). This was also an important step towards the 'establish supplier relationship' principle of forming long-term relationships with 
a small number of suppliers which can help to improve communication and mutual understanding (Holti et al. 2000).

\subsubsection{Use Collaborative ICT Systems}

ABC Construction's supply chain management approach was supported by a bespoke supply chain ICT intranet system that facilitated the sharing of data and information about the supply chain across their business. This ICT system hosted the database with records of a subcontractor's previous performance, previous spend levels, and all the relevant documentation obtained during the audit, including key subcontractor contact persons. The database was composed of approximately 5000 supply chain firms nationally. It was a functional intranet system for raising and reviewing important information and performance records about a subcontractor during supply chain procurement at the front end of the project. Project-based staff could review subcontractor performance, conduct localism mapping, and compile a pool of firms to send out tender enquiries. The project team could also review active workload capacity as the ICT intranet system provided an update of work that had been sublet to any supply chain firm within $A B C$ Construction. This was a very useful tool for generating intelligence about supply chain subcontractors to make effective procurement decisions.

ABC Construction also had an ICT project extranet system that facilitated data and information exchanges with the supply chain. This project extranet had e-tendering capabilities. It supported early supply chain involvement in design, specification development, value engineering, planning, and cost compilation. At tendering stage, $\mathrm{ABC}$ Construction shared project information with the subcontractors that contributed to their work winning activities. The ICT system was instrumental in facilitating supply chain collaboration during tender preparation and then later, project delivery. These ICT systems were very instrumental for collaboration between $\mathrm{ABC}$ Construction and the Tier 2 supply chain subcontractors. Although BIM was mentioned, this was driven on a project-by-project basis and was not relied upon as the main ICT system for supporting supply chain collaboration at the organisational level. However, some evidence from Papadonikolaki et al. (2016) suggests that BIM can play a greater role in fostering supply chain partnering.

\subsubsection{Measure Performance of Supply Chain Firms}

The performance of subcontractors had to be consistently rated by ABC Construction's project team on every project and logged onto the supply chain ICT intranet system. As a requirement, site management staff had to score subcontractors four times a year, depending on their duration on the project. Performance was scored on health and safety, standard of work, compliance with programme, contractual cooperation, financial cooperation, supervision of work, and where applicable, design input. There was also a section for the site management team to provide additional performance-related comments about a subcontractor. Apart from the health and safety performance scores that could be disclosed to subcontractors, only Level 1 subcontractors could review all their performance scores with $\mathrm{ABC}$ Construction during annual review meetings. Otherwise, it was for internal company use to review subcontractor performance, determine supply chain classification, and support selection of supply chain firms at the project level. The subcontractor performance scores contributed to the usefulness of ABC Construction's ICT system by providing up-to-date information on performance 
based on which supply chain procurement decisions were made. The performance information was also used to maintain fluidity in the supply chain, as subcontractors higher up the supply chain levels were always made aware that they could be demoted to lower levels if their performance faltered. This practice was instrumental in preventing supply chain subcontractors from being complacent.

\subsubsection{Engage in Continuous Performance Improvement Activities}

The competitive performance of the supply chain value stream is dependent on continuous learning and development in the supply chain (Hayes 2007). ABC Construction organised supply chain workshops (supplier days) on BIM, health and safety, and sustainability. They worked collaboratively with their supply chain to set standards on reducing the environmental impact of projects, and provided apprenticeships and training for local communities to achieve social value benefits. It was evident that sustainability benefits, particularly social value contributions, could not improve if $\mathrm{ABC}$ Construction did not work together with their supply chain to spread understanding of these issues and provide the necessary training. Subcontractors were also provided with training on how to create BIM components, use various BIM tools, and input data into BIM models. These supply chain workshops were to ensure that the entire supply chain as a unit progressed with initiatives that $A B C$ Construction was promoting across their business to improve project delivery. These interactions created knowledge exchange channels that contributed to operational improvements but only the Level 1 supply chain had the additional annual engagements to review performance scores and discuss improvement areas. Due to growing concerns about modern slavery in the construction supply chain, $\mathrm{ABC}$ Construction continues to work in partnership with their supply chain to identify risk areas and implement preventive measures.

\subsubsection{Develop Long-Term Collaborative Relationships}

Relationships in the supply chain can be very diverse and have been classified into three distinct typologies by Meng (2012) comprising traditional adversarial, short-term collaborative, and long-term collaborative relationships. Traditional adversarial relationships have a transactional one-off, price-based focus and are driven by a win-lose noncollaborative mentality. This relationship can easily deteriorate due to poor communication in the supply chain, a culture of mistrust and disputes, ultimately yielding substandard performance. Long-term strategic collaborations are used to promote mutual supply chain benefits over the longer term. The nature of relationships that were developed with supply chain subcontractors depended on their status on the supply chain database (see Figure 12.4). ABC Construction developed strategic and formalised collaborative relationships with their Level 1 subcontractors. They formalised the supply chain partnership by signing supply chain agreements to work closely together. There were around 5000 supply chain firms on ABC Construction's supply chain database. At the time of the study only around 250 firms belonged to the Level 1 classification as strategic supply chain partners. These firms were given the opportunity to price for all forthcoming work, although there was no guarantee of winning, and could meet ABC Construction's senior management on an annual basis to review the state of the supply chain collaboration. $\mathrm{ABC}$ Construction also counted on the Level 1 firms to provide early supply chain input through tendering assistance such as cost information, design input, and specification development. 
There were no formalised supply chain agreements with Level 2, Level 3, and Level 4 subcontractors, although short-term collaborations existed with Level 2 subcontractors, with the potential for progression to the next level - Level 1 subcontractors. To manage any risk of supply chain failure due to overdependence, and to achieve a degree of flexibility, $\mathrm{ABC}$ Construction maintained a pool of supply chain subcontractors for each work package across the various levels. This approach has been recommended by Gosling et al. (2010), who discussed the need to maintain a degree of sourcing flexibility by having a pool of suppliers in each category.

\subsubsection{Motivate and Incentivise the Supply Chain}

$\mathrm{ABC}$ Construction recognised the need to secure buy-in and commitment from their supply chain by promoting several practices. They created an annual best subcontractor award to recognise and reward subcontractors for exceptional performance. The underlying expectation for subcontractors that had won the best subcontractor award was that recognition for their exceptional performance through the award would contribute to future work winning opportunities and repeat business. Repeat business was the single most important incentivisation for subcontractors. It is not surprising that the opportunity for repeat business was used to secure the most commitment from the Level 1 subcontractors by giving them exclusive access to the pipeline of forthcoming work.

$\mathrm{ABC}$ Construction also promoted fair and prompt payment practices in their supply chain. Poor payment practices such as unfair valuations of work for payment, delayed payments, and delayed release of retention deductions, had all been recognised as negative practices that prevail in the construction supply chain. These unethical practices are so culturally embedded in the construction sector that some subcontractors receive payments $90-100+$ days after work has been completed and payments have been agreed. This unethical practice in the industry led $\mathrm{ABC}$ Construction to promote a 30 days payment policy for all their subcontractors.

\subsection{Conclusion}

This chapter has focused on supply chain management from a main contractor's perspective. A case study of a large UK main contractor, ABC Construction Company, has been used to evaluate their supply chain management practices. These practices, which comprised an audit of supply chain firms, performance measurement across projects, the use of collaborative ICT systems, engagement in continuous performance improvements, motivation and incentivisation of the supply chain, and prioritisation and promotion of long-term supply chain relationships with best performers, are reflective of supply chain management from a main contractor's organisational context. $\mathrm{ABC}$ Construction identified and built collaborative long-term supply chain relationships with the few trusted and committed supply chain subcontractors that provided them with a competitive advantage. These supply chain subcontractors were relied on for work winning support during tendering through early supply chain involvement in pricing, specification development, design contributions, and planning. All the supply chain management practices were adopted to promote integration and collaboration and enhance mutual competitive advantage by reacting as a single entity to maximise value creation for clients. A visible supply chain management team also acted as 
supply chain management champions in the organisation. What worked well with $\mathrm{ABC}$ Construction's supply chain management practice was the level of priority that they gave to supply chain subcontractors with Level 1 status:

since we've been a [Level 1], pretty much guaranteed at least $£ 1 \mathrm{~m}$ worth of turnover... We know what they've got coming in their pipeline, which is another reason for being a [Level 1], obviously you get exposure to that, we can then build in to our business plan for any one year

Contracts Manager, Carpentry and Joinery

Despite these efforts, some aspects of $\mathrm{ABC}$ Construction's supply chain management practice could have worked much better. It was not always possible to award contracts to supply chain subcontractors who had sometimes made significant tendering support at precontract stage. The main contractor had to sometimes audit new firms from the marketplace to obtain cheaper prices. The Construction Manager for ABC Construction, who appreciated the challenge with this approach during the projects remarked:

I think the biggest thing that can be done to manage the supply chain is actually to have fewer [firms] and work with them closely and actually negotiate jobs with them. The problem you have is that, in this marketplace it's difficult to do, but in the future, that's certainly the way that I'd like to see it happening...

Another weakness is that $\mathrm{ABC}$ Construction's supply chain management practices are characteristically dyadic as they focus mainly on Tier 2 subcontractors. It did not extend to the other complex network of firms at the lower tiers of the supply chain (Tier 3, 4, and 5 subcontractors). This is largely reflective of the low level of supply chain management maturity in construction and the inability of main contractors to maximise their role as supply chain managers, despite the opportunity. For main contractors like $\mathrm{ABC}$ Construction to have a greater control of the extended tiers of supply firms further down the supply chain tiers, they will have to take a leap from dyadic to triadic sourcing arrangements. Triadic sourcing arrangements are tripartite arrangements that can be established between one buyer and two suppliers (Dubois and Fredriksson 2008). The buyer, as in this instance a Tier 1 contractor, establishes and manages two buyer-supplier relationships (one with the Tier 2 subcontractor and the other with the Tier 3 subcontractor), in addition to the direct relationship between the two suppliers (Tier 2 and Tier 3 subcontractor). Considerable effort will be needed to fully embed supply chain management practices in such triadic arrangements as part of the evolutionary journey towards supply chain management adoption by Tier 1 contractors.

Another area of improvement is the unexploited opportunity to incentivise the supply chain through prompt payments through the facilitation of seamless payments using collaborative ICT systems. The emergence of blockchain technology and smart contracts, which are still at the early stages of evolution, can provide a significant opportunity for main contractors like $\mathrm{ABC}$ Construction to extend the capabilities of their collaborative ICT systems so that firms across the supply chain network can receive payments immediately a precoded condition has been met. While such an ICT system could alter the current power dominance of main contractors and perhaps reflect another business model, it would represent a significant step towards mutually beneficial supply chain collaboration. 
For the industry to prosper, a clearer drive towards ethical practice is required. This has recently been highlighted by the much-publicised collapse of Carillion plc, a British multinational facilities management and construction services company. Members of the Business, Energy and Industrial Strategy and Work and Pensions Committees (House of Commons 2018) criticised the overall corporate culture. The collapse of Carillion plc clearly had a profound impact on its associated supply chains.

Carillion relied on its suppliers to provide materials, services, and support across its contracts, but treated them with contempt. Late payments, the routine quibbling of invoices, and extended delays across reporting periods were company policy. Carillion was a signatory of the Government's Prompt Payment Code, but its standard payment terms were an extraordinary 120 days. Suppliers could be paid in 45 days but had to take a cut for the privilege

(House of Commons 2018 p. 87).

It is obvious that merely signing up to codes of best practice and paying lip-service to business ethics will have no effect if sections of the construction industry, and specifically prominent and/or large organisations, continue to focus on their own short-term benefit. Those who lose the most in these supply chains are frequently the lower tier subcontractors. More ethical and inclusive practices need to be demanded by clients to ensure that cultures change, otherwise the imbalances in power along the supply chain will continue to lead to exploitation and nonlegitimate risk transferals to those least able to manage it.

\section{References}

Arantes, A., Ferreira, L.M.D., and Costa, A.A. (2015). Is the construction industry aware of supply chain management? The portuguese contractors' perspective. Supply Chain Management: An International Journal 20 (4): 404-414.

Ashby, A., Leat, M., and Hudson-Smith, M. (2012). Making connections: a review of supply chain management and sustainability literature. Supply Chain Management: An International Journal 17 (5): 497-516.

Behera, P., Mohanty, R., and Prakash, A. (2015). Understanding construction supply chain management. Production Planning \& Control 26 (16): 1332-1350.

Braun, V. and Clarke, V. (2006). Using thematic analysis in psychology. Qualitative Research in Psychology 3 (2): 77-101.

Broft, R., Badi, S.M., and Pryke, S. (2016). Towards supply chain maturity in construction. Built Environment Project and Asset Management 6 (2): 187-204.

Cheng, J.C., Law, K.H., Bjornsson, H. et al. (2010). Modeling and monitoring of construction supply chains. Advanced Engineering Informatics 24 (4): 435-455.

Chiang, Y.-H. (2009). Subcontracting and its ramifications: a survey of the building industry in Hong Kong. International Journal of Project Management 27 (1): 80-88.

Christopher, M.L. (2011). Logistics and Supply Chain Management, 4e. Edinburgh: Pearson Education Ltd.

Cooper, M.C., Lambert, D.M., and Pagh, J.D. (1997). Supply chain management: more than a new name for logistics. International Journal of Logistics Management, The 8 (1): 1-14. 
Dubois, A. and Fredriksson, P. (2008). Cooperating and competing in supply networks: making sense of a triadic sourcing strategy. Journal of Purchasing and Supply Management 14 (3): 170-179.

Egan, J. (1998). Rethinking Construction: The Report of the Construction Task Force. London: Department of the Environment, Transport and the Regions (DETR).

Eriksson, P.E. (2010). Improving construction supply chain collaboration and performance: a lean construction pilot project. Supply Chain Management 15 (5): 394-403.

Fernie, S. and Tennant, S. (2013). The non-adoption of supply chain management. Construction Management and Economics 31 (10): 1038-1058.

Gosling, J., Purvis, L., and Naim, M.M. (2010). Supply chain flexibility as a determinant of supplier selection. International Journal of Production Economics 128 (1): 11-21.

Hayes, J. (2007). The Theory and Practice of Change Management. Palgrave Macmillan Basingstoke.

Holti, R., Nicolini, D., and Smalley, M. (2000). Building Down Barriers: Prime Contractor Handbook of Supply Chain Management. Ministry of Defence.

House of Commons (2018) Energy and Industrial Strategy and Work and Pensions Committees - Carillion. Report, together with formal minutes relating to the report: https://publications.parliament.uk/pa/cm201719/cmselect/cmworpen/769/769.pdf (accessed August 2019).

Karim, K., Marosszeky, M., and Davis, S. (2006). Managing subcontractor supply chain for quality in construction. Engineering, Construction and Architectural Management 13 (1): 27-42.

Kumaraswamy, M.M., Anvuur, A.M., and Smyth, H.J. (2010). Pursuing "relational integration" and "overall value" through "rivans". Facilities 28 (13/14): 673-686.

Lambert, D.M. and Cooper, M.C. (2000). Issues in supply chain management. Industrial Marketing Management 29 (1): 65-83.

Lönngren, H.M., Rosenkranz, C., and Kolbe, H. (2010). Aggregated construction supply chains: success factors in implementation of strategic partnerships. Supply Chain Management: An International Journal 15 (5): 404-411.

Manu, P., Ankrah, N., Proverbs, D., and Suresh, S. (2013). Mitigating the health and safety influence of subcontracting in construction: the approach of main contractors. International Journal of Project Management 31 (7): 1017-1026.

Manu, E., Ankrah, N., Chinyio, E., and Proverbs, D. (2015). Trust influencing factors in main contractor and subcontractor relationships during projects. International Journal of Project Management 33 (7): 1495-1508.

Meng, X. (2012). The effect of relationship management on project performance in construction. International Journal of Project Management 30 (2): 188-198.

Mentzer, J.T., DeWitt, W., Keebler, J.S. et al. (2001). Defining supply chain management. Journal of Business Logistics 22 (2): 1-25.

Pala, M., Edum-Fotwe, F., Ruikar, K. et al. (2014). Contractor practices for managing extended supply chain tiers. Supply Chain Management: An International Journal 19 (1): 31-45.

Papadonikolaki, E., Vrijhoef, R., and Wamelink, H. (2016). The interdependences of bim and supply chain partnering: empirical explorations. Architectural Engineering and Design Management 12 (6): 476-494.

Proverbs, D. and Gameson, R. (2008). Case study research. In: Advanced Research Methods in the Built Environment (eds. A. Knight and L. Ruddock), 99-110. Chichester, UK: Wiley. 
Ronchi, S. (2006). Managing subcontractors and suppliers in the construction industry. Supply Chain Forum: An International Journal 7: 24-33.

Segerstedt, A., Olofsson, T., Hartmann, A., and Caerteling, J. (2010). Subcontractor procurement in construction: the interplay of price and trust. Supply Chain Management: An International Journal 15 (5): 354-362.

Seth, D., Nemani, V.K., Pokharel, S., and Al Sayed, A.Y. (2018). Impact of competitive conditions on supplier evaluation: a construction supply chain case study. Production Planning E Control 29 (3): 217-235.

Smyth, H. (2010). Construction industry performance improvement programmes: the UK case of demonstration projects in the 'continuous improvement' programme. Construction Management and Economics 28 (3): 255-270.

Tam, V.W.Y., Shen, L., and Kong, J.S.Y. (2011). Impacts of multi-layer chain subcontracting on project management performance. International Journal of Project Management 29 (1): 108-116.

Thunberg, M. and Fredriksson, A. (2018). Bringing planning back into the picture-how can supply chain planning aid in dealing with supply chain-related problems in construction? Construction Management and Economics: 1-18.

Thunberg, M., Rudberg, M., and Karrbom Gustavsson, T. (2017). Categorising on-site problems: a supply chain management perspective on construction projects. Construction Innovation 17 (1): 90-111.

Winch, G. (1998). The growth of self-employment in British construction. Construction Management and Economics 16 (5): 531-542.

Yin, R.K. (2013). Case Study Research: Design and Methods, 5e, vol. 6. Sage Publications, Inc. 
